\title{
PERSEPSI DAN PERILAKU MASYARAKAT TERHADAP AIR LIMBAH YANG DIHASILKAN DAN KUALITAS AIR TUKAD RANGDA, KOTA DENPASAR, PROVINSI BALI
}

\author{
Ni Luh Putu Mega Priantari ${ }^{1{ }^{*}}$, I Wayan Budiarsa Suyasa ${ }^{2)}$, I Wayan Windia ${ }^{3)^{4}}$ \\ 1)Dinas Lingkungan Hidup dan Kebersihan Kota Denpasar, \\ ${ }^{2)}$ Fakultas Matematika dan Ilmu Pengetahuan Alam Universitas Udayana \\ ${ }^{3)}$ Fakultas Pertanian Universitas Udayana \\ *Email : mega_labu@yahoo.com
}

\section{ABSTRACT \\ COMMUNITY BEHAVIOR AND PERCEPTION TO WASTE WATER PRODUCT AND WATER QUALITY OF TUKAD RANGDA, DENPASAR TOWN, BALI PROVINCE}

Many activities and the continuous disposal of waste water has resulted water pollution in Tukad Rangda. Tukad Rangda's water quality over the last five years (2012-2016) indicated experiencing contamination with decreasing water quality. The condition indicates the need of serious effort to maintain the water quality of Tukad Rangda. The purpose of this research is to know the perception and behavior of head of household and businesses in conducting waste water management that potentially causing Tukad Rangda water contamination, determining water quality and water quality status based on the Pollution Index, and determining appropriate alternative strategies to control water pollution in Tukad Rangda.

Sample was collected by purposive sampling. Water samples was taken at three point: on the upstream, middle, and downstream of Tukad Rangda. Samples are analyzed in situ and in laboratory. Determination of perception and community behavior based on questionnaires and interviews to households and businesses. The data obtained were analyzed by force-field analysis to determine alternative strategy of Tukad Rangda water contamination control.

The results of perception analysis of households and businesses on waste water management that has the potential to cause Tukad Rangda water contamination shows well-categorized results. However, for the behavior of head of households and businesses on waste water management that potentially causing Tukad Rangda water pollution, each of them showing results that can be categorized as quite good and less good respectively. Water quality of Tukad Rangda at upstream, middle, and downstream areas have exceeded the water quality standard class II in accordance with the Bali Governor Regulations No. 16 year 2016 for these parameters: BOD, COD, phosphate, and lead. Water quality status of Tukad Rangda based on Method of Pollution Index at upstream, middle, and downstream classified slightly contaminated. Based on force-field analysis, the alternative strategy obtained is increasing the insight and understanding about waste water management to the community, water waste management regulation at household scale, coaching, supervision, and law enforcement against businesses violating the applicable regulations, providing waste water treatment facilities, as well as the development of Tukad Rangda as water tourism area through the involvement of community participation.

Keywords: Perception, Behavior, Water Quality, Pollution Index, Tukad Rangda

\section{PENDAHULUAN}

Terjadinya degradasi kualitas air sebagai dampak pesatnya laju pembangunan merupakan hal yang tidak dapat dihindari. Hal tersebut terutama terjadi untuk kota-kota besar di Indonesia (Effendi, 2003). Pertumbuhan Kota Denpasar di samping telah menghasilkan kemajuan-kemajuan dalam berbagai bidang penghidupan dan kehidupan perkotaan juga telah menimbulkan masalah pembangunan dan perkembangan perkotaan yang tidak kecil. Salah satu permasalahan yang langsung dapat dirasakan adalah terjadinya pencemaran lingkungan, baik pencemaran udara, pencemaran tanah, maupun pencemaran air (Perda Kota Denpasar No. 27, 2011).

Tukad Rangda merupakan salah satu sungai yang berada di Kota Denpasar yang melintasi wilayah Kecamatan Denpasar Selatan dan Kecamatan Denpasar Timur. Tukad Rangda dalam pemanfaatannya lebih banyak digunakan untuk pembuangan saluran irigasi, drainase, dan air limbah oleh masyarakat sekitar (BLH Kota 
Denpasar, 2015). Pembuangan limbah yang dilakukan secara terus-menerus ke dalam sungai inilah yang kemudian menimbulkan terjadinya pencemaran air dan rusaknya lingkungan badan perairan (Setiari dkk., 2012). Berdasarkan data hasil pengujian kualitas air Tukad Rangda yang dilakukan oleh Badan Lingkungan Hidup Kota Denpasar selama kurun waktu lima tahun terakhir yaitu tahun 2012-2016, diketahui bahwa kondisi air Tukad Rangda terindikasi mengalami pencemaran. Beberapa parameter yang melampaui baku mutu air kelas dua berdasarkan Peraturan Gubernur Bali No. 16 Tahun 2016 yaitu parameter TSS, DO, BOD, COD, nitrit, nitrat, fosfat, kadmium, timbal, dan coliform. Bahkan untuk parameter BOD di daerah hulu dan tengah baik pada saat musim hujan maupun musim kemarau cenderung mengalami peningkatan dari tahun 2012 sampai tahun 2016. Kondisi tersebut mengindikasikan perlunya upaya pengelolaan yang serius untuk menjaga kualitas air Tukad Rangda.

Kualitas air sungai sangat dipengaruhi oleh persepsi dan perilaku masyarakat sebagai penyumbang beban pencemar sungai. Hal ini mengingat masukkan buangan air limbah ke sungai dipengaruhi oleh aktivitas masyarakat di sekitarnya. Berdasarkan hal tersebut menimbulkan ide untuk mengadakan penelitian di Tukad Rangda. Tujuan Penelitian adalah (1) untuk mengetahui persepsi dan perilaku komponen rumah tangga dan pihak pelaku usaha dalam melakukan pengelolaan air limbah yang berpotensi menimbulkan pencemaran air Tukad Rangda, (2) menentukan kualitas air dan status mutu air Tukad Rangda berdasarkan Indeks Pencemaran, (3) menentukan alternatif strategi pengendalian pencemaran air yang sesuai diterapkan untuk Tukad Rangda.

\section{METODOLOGI}

\subsection{Lokasi dan Waktu Penelitian}

Penelitian dilakukan di Tukad Rangda, yang melintasi wilayah Kecamatan Denpasar Selatan dan Denpasar Timur Kota Denpasar. Pada penentuan persepsi dan perilaku masyarakat terhadap pengelolaan air limbah yang berpotensi menimbulkan pencemaran air Tukad Rangda, lokasi yang dipilih yaitu kegiatan rumah tangga atau usaha yang berada di sepanjang aliran Tukad Rangda yang air limbahnya menuju aliran air Tukad Rangda. Penelitian ini dilaksanakan pada bulan Januari Februari 2017.

\subsection{Prosedur Penelitian}

Prosedur penelitian yang dilakukan, yaitu persiapan penelitian yang meliputi penyiapan form lapangan, penyiapan peralatan sampel air, personil pengambil sampel air, transportasi, form isian kuesioner. Selanjutnya dilakukan pengambilan sampel air berdasarkan debit air sungai, pengukuran parameter lapangan, pengujian kualitas air di Laboratorium Analitik Universitas Udayana. Pengumpulan data persepsi dan perilaku masyarakat dilakukan melalui penyebaran kuesioner untuk komponen rumah tangga dan pelaku usaha.

\subsection{Prosedur Analisis}

Proses analisis data persepsi dan perilaku masyarakat dilakukan melalui analisis deskriptif kualitatif dengan skala likert dan model biner. Penetapan kelayakan kualitas air dilakukan dengan membandingkan hasil pengukuran dari masingmasing parameter air dengan nilai baku mutu berdasarkan Peraturan Gubernur Bali No. 16 Tahun 2016, sedangkan penentuan status mutu air dilakukan dengan metode Indeks Pencemaran. Analisis strategi pengendalian pencemaran air dilakukan dengan force-field analysis (analisis medan kekuatan).

\section{HASIL DAN PEMBAHASAN}

\subsection{Persepsi Komponen Rumah Tangga dan Pelaku Usaha terhadap Pengelolaan Air Limbah yang Berpotensi Menimbulkan Pencemaran Air Tukad Rangda}

Berdasarkan hasil pengukuran persepsi komponen rumah tangga diketahui bahwa rata-rata persepsi komponen rumah tangga terhadap pengelolaan air limbah yang berpotensi menimbulkan pencemaran air Tukad Rangda terkategori baik. Berdasarkan hasil pengukuran, diperoleh bahwa dari 50 responden sebanyak 48 orang atau $96 \%$ mempunyai persepsi yang baik. Sisanya masing-masing satu orang mempunyai persepsi yang kurang baik dan cukup baik, seperti yang ditunjukkan pada Gambar 1. Adapun indikator yang diukur yaitu persepsi komponen rumah tangga terhadap penyediaan sarana pengolahan air limbah, persepsi terhadap pemeliharaan sarana pengolahan air limbah, persepsi terhadap minimisasi air limbah, persepsi terhadap definisi pencemaran air, persepsi terhadap penyebab pencemaran air, dan persepsi terhadap dampak pencemaran air.

Pada komponen pelaku usaha, rata-rata persepsi terhadap pengelolaan air limbah yang berpotensi menimbulkan pencemaran air Tukad Rangda juga terkategori baik. Berdasarkan hasil pengukuran, diketahui bahwa dari 20 responden sebanyak 15 orang atau $75 \%$ mempunyai persepsi yang baik. Sisanya masing-masing empat orang atau $20 \%$ dan satu orang atau 5\% mempunyai persepsi yang cukup baik dan kurang baik, seperti yang disajikan pada Gambar 2 .

Adapun indikator yang diukur yaitu persepsi komponen pelaku usaha terhadap penyediaan sarana pengolahan air limbah, persepsi terhadap pemeliharaan sarana pengolahan air limbah, persepsi 
terhadap minimisasi air limbah, persepsi terhadap ketaatan perizinan lingkungan yang dimiliki, persepsi terhadap ketaatan ketentuan teknis IPAL, persepsi terhadap ketaataan pengujian kualitas air limbah, persepsi terhadap definisi pencemaran air, persepsi terhadap penyebab pencemaran air, dan persepsi terhadap dampak pencemaran air. Jika ditinjau dari indikator persepsi, diketahui bahwa pada komponen pelaku usaha terdapat dua indikator yang masih terkategori cukup yaitu persepsi usaha laundry dan ternak babi terhadap penyediaan sarana pengolahan air limbah dan Persepsi usaha laundry, ternak babi, dan hotel terhadap ketaatan pengujian kualitas air limbah yang masing-masing terkategori cukup.

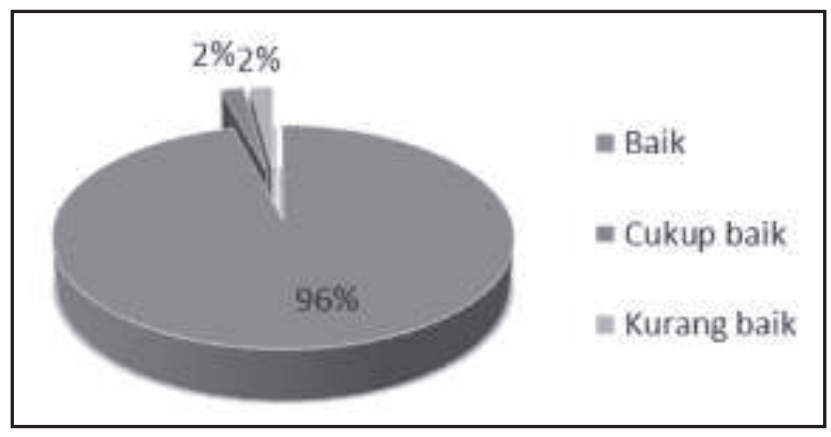

Gambar 1

Persepsi Komponen Rumah Tangga terhadap Pengelolaan Air Limbah yang Berpotensi Menimbulkan Pencemaran Air Tukad Rangda

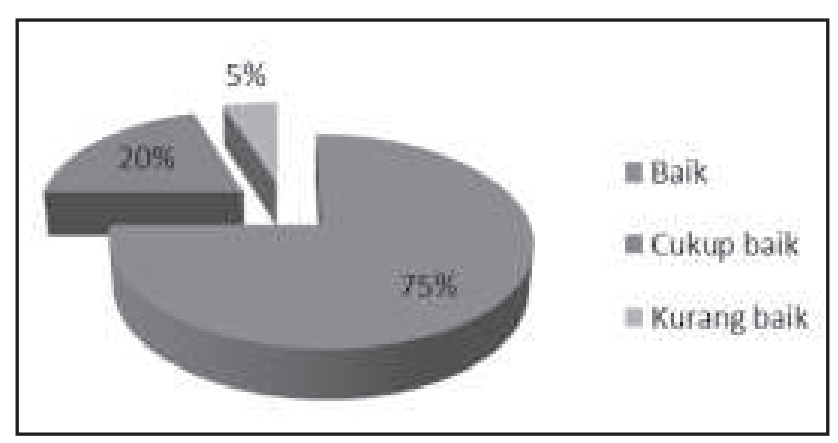

Gambar 2

Persepsi Komponen Pelaku Usaha terhadap Pengelolaan Air Limbah yang Berpotensi Menimbulkan Pencemaran Air Tukad Rangda

\subsection{Perilaku Komponen Rumah Tangga dan Pelaku Usaha terhadap Pengelolaan Air Limbah yang Berpotensi Menimbulkan Pencemaran Air Tukad Rangda}

Rata-rata perilaku komponen rumah tangga terhadap pengelolaan air limbah yang berpotensi menimbulkan pencemaran air Tukad Rangda terkategori cukup baik. Berdasarkan hasil pengukuran, diperoleh bahwa dari 50 responden sebanyak 44 orang atau $88 \%$ mempunyai perilaku yang cukup baik dan sisanya sebanyak enam orang mempunyai perilaku yang kurang baik, seperti yang terlihat pada Gambar 3. Indikator yang diukur pada penentuan perilaku komponen rumah tangga terhadap pengelolaan air limbah yang berpotensi menimbulkan pencemaran air Tukad Rangda yaitu perilaku terhadap upaya pengolahan air limbah, perilaku terhadap upaya pemeliharaan sarana pengolahan air limbah, dan perilaku terhadap upaya minimisasi air limbah.

Jika dikaitkan antara perilaku dengan persepsi komponen rumah tangga terhadap pengelolaan air limbah yang berpotensi menimbulkan pencemaran air Tukad Rangda maka terjadi ketidaksesuaian, dimana persepsi terkategori baik sedangkan perilaku cukup baik. Hal ini dapat terjadi karena belum adanya regulasi atau ketentuan yang mengatur pengelolaan air limbah rumah tangga di Kota Denpasar, seperti yang telah diberlakukan di Provinsi DKI Jakarta. Dalam rangka mengatasi masalah air limbah rumah tangga, Pemerintah Provinsi DKI Jakarta telah menerbitkan Peraturan Gubernur Propinsi DKI Jakarta Nomor 122 Tahun 2005 tentang Pengelolaan Air Limbah Domestik di Provinsi Daerah Khusus Ibukota Jakarta. Berdasarkan Peraturan Gubernur tersebut seluruh air limbah rumah tangga baik air limbah toilet maupun air limbah non toilet harus diolah dengan unit pengolahan air limbah di tempat (on site treatment), baru selanjutnya air olahannya dibuang ke saluran umum.

Jika ditinjau dari karakteristik responden pada komponen rumah tangga dari aspek ekonomi, diketahui bahwa sebanyak 54\% komponen rumah tangga memiliki pendapatan perbulan di bawah UM Kota Denpasar dan sebanyak 54\% menempati tempat tinggal dengan status sewa/ kontrak yaitu tersebar di Jl. Pendidikan Gg. Sanitasi, Desa Sidakarya dan di Jl. Tegal Wangi serta Jl. Cenigan Sari, Kelurahan Sesetan. Hal tersebut dapat mengindikasikan bahwa masyarakat mempunyai kesulitan dalam membangun fasilitas sanitasi yang layak/ memadai.

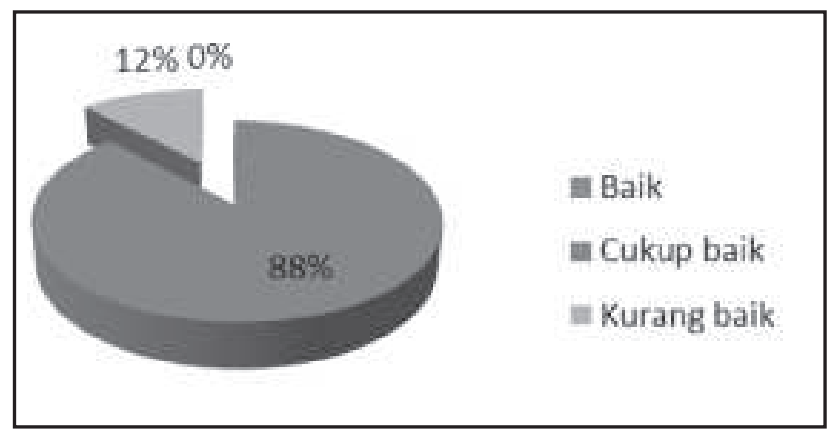

Gambar 3

Perilaku Komponen Rumah Tangga terhadap Pengelolaan Air Limbah yang Berpotensi Menimbulkan Pencemaran Air Tukad Rangda

Pada penentuan perilaku komponen pelaku usaha diketahui bahwa rata-rata perilaku komponen pelaku usaha terhadap pengelolaan air limbah yang berpotensi menimbulkan pencemaran air Tukad Rangda terkategori kurang baik. Berdasarkan hasil pengukuran, diperoleh bahwa dari 20 responden 
sebanyak 3 orang atau 15\% mempunyai perilaku yang cukup baik yang berasal dari usaha laundry, ternak babi, dan hotel sedangkan sisanya sebanyak 17 orang atau $85 \%$ mempunyai perilaku yang kurang baik, seperti disajikan pada Gambar 4. Indikator yang diukur pada penentuan perilaku komponen pelaku usaha terhadap pengelolaan air limbah yang berpotensi menimbulkan pencemaran air Tukad Rangda yaitu perilaku terhadap upaya pengolahan air limbah, perilaku terhadap upaya pemeliharaan sarana pengolahan air limbah, perilaku terhadap ketaatan perizinan lingkungan yang dimiliki, dan perilaku terhadap ketaatan pengujian kualitas air limbah.

Berdasarkan hasil analisis tersebut diketahui bahwa antara perilaku dengan persepsi komponen pelaku usaha terhadap pengelolaan air limbah yang berpotensi menimbulkan pencemaran air Tukad Rangda terjadi ketidaksesuaian, yaitu persepsi terkategori baik sedangkan perilaku terkategori kurang baik. Hal ini dapat terjadi karena kurangnya kepedulian atau kesadaran terhadap pentingnya melakukan pengelolaan air limbah. Selain itu, jika ditinjau dari karakteristik responden komponen pelaku usaha dari aspek ekonomi diketahui bahwa sebanyak $85 \%$ status lahan usahanya adalah kontrak/ sewa dan sebanyak $90 \%$ komponen pelaku usaha merupakan usaha rumah tangga dengan jumlah karyawan satu sampai sembilan orang sehingga para pelaku usaha tersebut mengalami kesulitan dalam melakukan pengelolaan air limbah yang dihasilkannya.

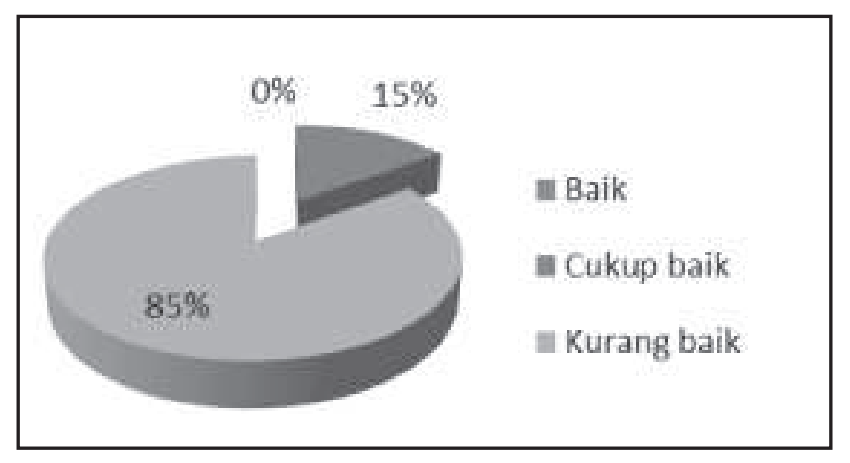

Perilaku Komponen Pelaku Usaha terhadap Pengelolaan Air Limbah yang Berpotensi Menimbulkan Pencemaran Air Tukad Rangda

\subsection{Hasil Analisis Kualitas Air}

\subsubsection{Debit dan suhu}

Debit air Tukad Rangda selama pengambilan sampel berkisar antara 0,0032 m3/dt sampai 0,1959 m3/dt. Debit air Tukad Rangda pada bagian hulu lebih kecil dibandingkan bagian tengah. Hal ini disebabkan karena adanya penambahan volume air yang berasal dari aktivitas rumah tangga (domestik) dan berbagai aktivitas lainnya yang ada di sepanjang aliran Tukad Rangda, khususnya bagian tengah.
Nilai debit tersebut kemudian mengalami penurunan di bagian hilir. Hal ini karena kecepatan aliran air di bagian hilir lebih kecil dibandingkan dengan di bagian tengah. Debit diketahui berbanding lurus dengan luas penampang dan kecepatan aliran, sehingga semakin kecil kecepatan aliran maka debit juga akan semakin mengecil (Norhadi dkk., 2015).

Suhu air Tukad Rangda berkisar berkisar $25,0^{\circ} \mathrm{C}$ sampai $30,0^{\circ} \mathrm{C}$. Suhu badan air dipengaruhi oleh musim, lintang (latitude), ketinggian dari permukaan laut (altitude), waktu dalam hari, sirkulasi udara, penutupan awan, dan aliran serta kedalaman badan air (Effendi, 2003). Berdasarkan hasil penelitian rata-rata suhu air di bagian hulu dan tengah lebih tinggi dibandingkan di bagian hilir. Pada bagian hulu dan tengah diketahui terdapat usaha tahu tempe. Limbah tahu dan tempe yang berasal dari air rebusan kedelai dapat menyebabkan peningkatan suhu air Tukad Rangda. Peningkatan dan penurunan suhu dalam air dipengaruhi oleh komposisi substrat, kekeruhan, curah hujan, angin, suhu limbah, dan reaksi-reaksi kimia yang terjadi dalam air (Suyasa, 2015).

\subsubsection{Total Dissolved Solid (TDS) dan Total Suspended Solid (TSS)}

Rata-rata konsentrasi TDS air Tukad Rangda pada bagian hulu, tengah, dan hilir menunjukkan peningkatan dari bagian hulu ke hilir, namun dengan nilai yang masih memenuhi baku mutu air kelas II sesuai Peraturan Gubernur Bali No. 16 Tahun 2016. Adapun rata-rata nilai TDS dari hulu ke hilir berturut-turut $150 \mathrm{mg} / \mathrm{L} ; 210 \mathrm{mg} / \mathrm{L} ; 293,3 \mathrm{mg} / \mathrm{L}$. Peningkatan konsentrasi TDS dari bagian hulu ke hilir tersebut menunjukkan telah terjadi peningkatan hasil reaksi alam dan peningkatan proses pembusukan dari hulu ke hilir. Nilai TDS pada bagian hilir dan tengah yang lebih tinggi dibandingkan bagian hulu dapat disebabkan karena banyaknya aktivitas yang terdapat pada bagian tengah dan hilir seperti peternakan, rumah tangga, industri tahu dan tempe, cuci kendaraan bermotor, laundry, dan hotel.

Rata-rata nilai TSS air Tukad Rangda dari hulu ke hilir berturut-turut 1,1117 mg/L; 8,1030 mg/L; $3,1343 \mathrm{mg} / \mathrm{L}$. Tingginya nilai TSS di bagian tengah tersebut menunjukkan bahwa kandungan padatan tersuspensi seperti jasad-jasad renik, lumpur, dan pasir halus pada bagian tengah lebih tinggi dibandingkan bagian hilir dan hulu. Tingginya nilai TSS di bagian tengah tersebut disebabkan karena banyaknya aktivitas penduduk di bagian tengah seperti ternak babi yang tidak mengolah air limbah yang dihasilkannya sehingga menyebabkan tingginya konsentrasi TSS. Selain itu, dapat juga disebabkan karena adanya pengikisan sedimen yang banyak terdapat pada pinggiran sungai pada bagian tengah. 


\subsection{3. $\mathrm{pH}$}

Berdasarkan hasil analisis diketahui rata-rata nilai $\mathrm{pH}$ dari hulu ke hilir cenderung semakin meningkat, dengan nilai berturut-turut sebesar 7,17; 7,$20 ; 7,24$. Hal ini disebabkan karena banyaknya aktivitas rumah tangga dan laundry di bagian tengah sampai hilir yang membuang air limbahnya ke Tukad Rangda. Air limbah domestik yang dihasilkan dari aktivitas rumah tangga dan air limbah laundry tersebut diketahui bersifat basa. Hal ini karena sifat dari detergen bersifat basa sehingga sisa/residu dari detergen sehabis mencuci pakaian larut bersama air

\subsubsection{Oksigen Terlarut (DO)}

Kandungan oksigen terlarut (DO) air Tukad Rangda pada bagian hulu, tengah, dan hilir berturutturut sebesar 4,459 mg/L; 4,368 mg/L; 4,323 mg/L. Walaupun rata-rata kandungan DO dari bagian hulu ke hilir cenderung mengalami penurunan, namun masih memenuhi baku mutu air kelas II sesuai Peraturan Gubernur Bali No. 16 Tahun 2016, yaitu di atas $4 \mathrm{mg} / \mathrm{L}$. Penurunan nilai DO terjadi karena adanya peningkatan beban oksidasi dari bahan-bahan organik atau bahan-bahan penurun oksigen seperti limbah deterjen, limbah domestik, limbah dari industri tahu tempe, dan limbah usaha ternak, sehingga semakin ke hilir semakin banyak oksigen yang dibutuhkan untuk mengoksidasi bahan-bahan organik oleh mikroorganisme.

\subsubsection{Kebutuhan oksigen biokimiawi (BOD)}

Rata-rata nilai BOD air Tukad Rangda dari bagian hulu ke hilir cenderung mengalami peningkatan, dengan nilai rata-rata berturut-turut sebesar 13,326 mg/L; 13,687 mg/L; 15, $197 \mathrm{mg} / \mathrm{L}$. Hal ini disebabkan karena semakin ke hilir jumlah bahan pencemar organik yang ada semakin bertambah sehingga lebih banyak oksigen yang diperlukan untuk mengoksidasi bahan-bahan pencemar tersebut. Tingginya bahan pencemar organik pada bagain tengah dan hilir disebabkan karena banyaknya aktivitas rumah tangga, usaha tempe tahu, dan peternakan yang membuang air limbahnya ke Tukad Rangda.

Tingginya beban pencemar BOD dari aktivitas rumah tangga tersebut dapat terjadi mengingat Tukad Rangda berada di wilayah perkotaan. Sungai di perkotaan diketahui rentan mengalami pencemaran karena banyaknya penduduk dan banyaknya pembuangan air limbah rumah tangga ke dalam sungai. Hal tersebut diperparah dengan perubahan gaya hidup penduduk seperti perubahan pola makan untuk hidup, tingginya tingkat konsumtif penduduk dan sebagainya (JEMAI, 1999).

\subsubsection{Kebutuhan oksigen kimiawi (COD)}

Rata-rata nilai COD dari hulu ke hilir juga mengalami peningkatan, dengan nilai rata-rata berturut-turut sebesar 27,769 mg/L; 28,877 mg/L; $30,308 \mathrm{mg} / \mathrm{L}$. Kondisi ini menunjukkan bahwa semakin ke hilir terjadi peningkatan beban pencemar bahan-bahan organik baik yang dapat didegradasi secara biologis (biodegradable) maupun yang sukar didegradasi secara biologis (non biodegradable). Hal ini dapat terjadi mengingat adanya aktivitas rumah tangga, peternakan, usaha tahu tempe, hotel, laundry, cuci kendaraan bermotor yang memanfaatkan bahan-bahan organik baik yang biodegradable maupun non biodegradable seperti deterjen yang dapat meningkatkan konsentrasi COD perairan.

\subsubsection{Fosfat $\left(\mathrm{PO}_{4}\right)$}

Rata-rata konsentrasi fosfat dari bagian hulu ke hilir Tukad Rangda diketahui mengalami peningkatan, dengan nilai rata-rata berturut-turut sebesar 2,361 mg/L; 2,906 mg/L; 3,408 mg/L. Hal ini disebabkan karena banyaknya aktivitas rumah tangga dan usaha laundry, serta cuci kendaraan bermotor yang ada di sepanjang aliran Tukad Rangda. Limbah domestik dari aktivitas penduduk dan limbah laundry diketahui mengandung deterjen. Penggunaan deterjen untuk mencuci dapat meningkatkan konsentrasi fosfat di perairan. Polifosfat dari deterjen diperkirakan memberikan kontribusi sekitar 50\% dari seluruh fosfat yang ada di perairan (Effendi, 2003).

\subsubsection{Timbal (Pb)}

Konsentrasi timbal air Tukad Rangda pada bagian hulu, tengah, dan hilir berkisar 0,109-0,129 $\mathrm{mg} / \mathrm{L}$. Konsentrasi tersebut telah melebihi baku mutu air kelas II sesuai Peraturan Gubernur Bali No. 16 Tahun 2016, yaitu sebesar 0,03 mg/L. Ratarata konsentrasi timbal dari hulu ke hilir diketahui mengalami peningkatan. Hal ini disebabkan karena adanya aktivitas bengkel dan cuci kendaraan bermotor yang buangan air limbahnya mengalir ke Tukad Rangda. Selain itu, logam ini dapat masuk ke perairan melalui pengkristalan $\mathrm{Pb}$ di udara dengan bantuan air hujan. Bahan bakar yang mengandung timbal juga memberikan kontribusi yang berarti bagi keberadaan timbal dalam air (Effendi, 2003).

\subsubsection{Fecal coliform dan total coliform}

Konsentrasi fecal coliform air Tukad Rangda pada bagian hulu, tengah, dan hilir pada ketiga tahap pengambilan sampel berkisar antara $10-31 \mathrm{MPN} /$ $100 \mathrm{~mL}$. Nilai tersebut memenuhi baku mutu air kelas II pada Peraturan Gubernur Bali No. 16 Tahun 2016 sebesar 1000 MPN/100 mL. Pencemaran fecal coliform di perairan ini bersumber dari aliran limbah domestik dari permukiman sekitarnya dan limbah kotoran ternak dari usaha peternakan babi yang banyak terdapat di bagian tengah dan hilir.

Konsentrasi total coliform air Tukad Rangda 
pada bagian hulu, tengah, dan hilir berkisar antara 1050 - 1100 MPN/100mL. Nilai tersebut masih memenuhi baku mutu air kelas II pada Peraturan Gubernur Bali No. 16 Tahun 2016 sebesar 5000 MPN/ $100 \mathrm{~mL}$. Adanya pencemaran bakteri coliform disebabkan oleh adanya pembuangan air limbah domestik, usaha peternakan babi, dan hewan atau tanaman yang telah mati.

\subsection{Indeks Pencemaran (IP)}

Adapun rata-rata nilai Indeks Pencemaran air Tukad Rangda pada bagian hulu, tengah, dan hilir cenderung mengalami peningkatan dari hulu ke hilir dan tergolong cemar ringan pada ketiga bagian tersebut. Rata-rata nilai indeks pencemaran air Tukad Rangda yang tergolong tercemar ringan tersebut menunjukkan bahwa kualitas air Tukad Rangda dari hulu ke hilir tidak dapat dimanfaatkan sesuai peruntukan air kelas II yaitu air yang dapat digunakan sebagai sarana/ prasarana rekreasi air, pembudidayaan ikan air tawar, peternakan, air untuk mengairi pertanaman, dan atau peruntukan lain yang mempersyaratkan mutu air yang sama dengan kegunaan tersebut. Ini berarti diperlukan strategi pengendalian pencemaran air Tukad Rangda sehingga dapat dimanfaatkan sesuai dengan peruntukan air kelas II berdasarkan Peraturan Gubernur Bali No. 16 Tahun 2016.

\subsection{Strategi Pengendalian Pencemaran Air Tukad Rangda}

Dengan force-field analysis strategi pengendalian pencemaran air Tukad Rangda diidentifikasi melalui beberapa aspek terkait meliputi aspek ekonomi, persepsi dan perilaku masyarakat, serta analisis kualitas air. Pada aspek persepsi, faktor yang menjadi pendorong terwujudnya pengendalian pencemaran air Tukad Rangda yaitu persepsi masyarakat yang terkategori baik terhadap pengelolaan air limbah yang berpotensi menimbulkan pencemaran air Tukad Rangda. Namun, tidak semua persepsi masyarakat dapat digolongkan sebagai faktor pendorong karena diketahui terdapat persepsi komponen pelaku usaha yaitu dari usaha laundry dan ternak babi yang terkategori cukup baik sehingga masih perlu ditingkatkan. Adapun pemahaman yang perlu ditingkatkan yaitu mengenai penyediaan sarana pengolahan air limbah baik melalui pembuatan IPAL atau pembuatan biogas kepada usaha laundry dan ternak babi dan peningkatan wawasan dan pemahaman tentang ketaatan pengujian kualitas air limbah kepada usaha laundry dan ternak babi.

Aspek ekonomi merupakan salah satu yang menjadi faktor penghambat dalam mewujudkan strategi pengendalian pencemaran air Tukad Rangda. Sebanyak 54\% komponen rumah tangga memiliki pendapatan perbulan di bawah UM Kota Denpasar dan menempati tempat tinggal dengan status sewa/ kontrak. Sedangkan sebanyak 85\% status lahan usaha untuk komponen pelaku usaha adalah kontrak/ sewa dan 75\% komponen pelaku usaha tergolong usaha kecil. Maka untuk mewujudkan strategi pengendalian pencemaran air Tukad Rangda diperlukan adanya kerjasama atau pemberian bantuan pembangunan IPAL komunal bagi warga, pemberian bantuan IPAL bagi usaha kecil seperti laundry atau pemberian bantuan biogas bagi usaha ternak oleh pemerintah atau pihak swasta melalui dana Corporate Social Responsibility (CSR).

Perilaku masyarakat yang terkategori cukup/ kurang baik terhadap pengelolaan air limbah salah satunya ditunjukkan oleh tidak tersedianya pengolahan air limbah pada hampir semua komponen pelaku usaha dan tidak tersedianya pengolahan air limbah dari aktivitas mencuci, mandi, dan dapur pada semua komponen rumah tangga. Perilaku tersebut tentu menyebabkan tercemarnya air Tukad Rangda. Hal tersebut ditandai dengan konsentrasi BOD, COD, fosfat, dan timbal air Tukad Rangda yang melebihi baku mutu. Selain itu, diketahui juga ratarata nilai Indeks Pencemaran air Tukad Rangda tergolong cemar sedang di bagian hulu, tengah, dan hilir.

Strategi yang dapat dilakukan untuk mengubah persepsi dan perilaku masyarakat yang masih terkategori cukup/ kurang baik terhadap pengelolaan air limbah yang berpotensi menimbulkan pencemaran air Tukad Rangda, diantaranya melalui sosialisasi, pembinaan, pengawasan, dan penegakan hukum oleh aparatur pemerintah baik di tingkat kota sampai ke tingkat desa/ dusun/ banjar. Selain itu, untuk menumbuhkan kecintaan masyarakat terhadap Tukad Rangda dapat juga dikembangkan destinasi wisata air Tukad Rangda dengan melibatkan peran serta masyarakat seperti yang telah dikembangkan di Tukad Bindu, Kota Denpasar dan di daerah-daerah lain seperti Sungai Kalimas di Surabaya atau Ekoriparian Ciliwung Srengseh Sawah di Jakarta.

\section{SIMPULAN DAN SARAN}

\subsection{Simpulan}

Berdasarkan hasil penelitian dapat disimpulkan bahwa rata-rata persepsi komponen rumah tangga dan pelaku usaha terhadap pengelolaan air limbah yang berpotensi menimbulkan pencemaran air Tukad Rangda terkategori baik, sedangkan untuk perilaku komponen rumah tangga terkategori cukup baik dan untuk komponen pelaku usaha terkategori kurang baik. Kualitas air Tukad Rangda pada wilayah hulu, tengah, dan hilir telah melebihi baku mutu air kelas II sesuai Peraturan Gubernur Bali No. 16 Tahun 2016 untuk parameter BOD, COD, fosfat, dan timbal, sedangkan untuk parameter $\mathrm{pH}$, DO, TSS, TDS, fecal coliform, dan total coliform masih 
memenuhi baku mutu. Status mutu air Tukad Rangda berdasarkan Metode Indeks Pencemaran pada wilayah hulu, tengah, dan hilir tergolong tercemar ringan.

Berdasarkan force-field analysis diperoleh alternatif strategi, yaitu peningkatan wawasan dan pemahaman melalui sosialisasi secara rutin tentang pengelolaan air limbah kepada masyarakat baik komponen rumah tangga maupun pelaku usaha, pembuatan regulasi pengelolaan air limbah skala rumah tangga, pembinaan, pengawasan, dan penegakan hukum terhadap pelaku usaha yang melanggar peraturan yang berlaku, pemberian bantuan sarana pengolahan air limbah kepada masyarakat di kawasan pemukiman padat dan kumuh serta usaha skala rumah tangga, serta pengembangan kawasan wisata air Tukad Rangda melalui pelibatan peran serta masyarakat.

\subsection{Saran}

Berdasarkan simpulan di atas dapat disarankan agar Pemerintah Daerah melalui Dinas Lingkungan Hidup dan Kebersihan Kota Denpasar dan Dinas Pekerjaan Umum dan Penataan Ruang Kota Denpasar dapat berkoordinasi dalam melakukan pengendalian pencemaran air Tukad Rangda dan pengembangan kawasan wisata air Tukad Rangda dengan melibatkan peran serta masyarakat dan pihak swasta melalui dana CSR. Dibutuhkan suatu Standar Prosedur Operasional (SPO) Pengelolaan Limbah Industri Skala Kecil/ Rumah Tangga untuk setiap jenis industri/ usaha mengingat usaha yang banyak berkembang tergolong usaha kecil/ rumah tangga.

\section{DAFTAR PUSTAKA}

Badan Lingkungan Hidup Kota Denpasar. 2015. Kajian Pemantauan Kualitas Air Sungai dan Air Laut di Kota Denpasar Kerjasama dengan UPT Laboratorium Analitik Universitas Udayana. Badan Lingkungan Hidup. Denpasar.

Badan Lingkungan Hidup Kota Denpasar. 2016. Kajian Pemantauan Kualitas Air Sungai dan Air Laut di Kota Denpasar Kerjasama dengan UPT Laboratorium Analitik Universitas Udayana. Badan Lingkungan Hidup. Denpasar.

Effendi, H. 2003. Telaah Kualitas Air Bagi Pengelolaan Sumberdaya dan Lingkungan Perairan. Penerbit Kanisius. Yogyakarta.

Japan Environmental Management Association For Industry (JEMAI). 1999. Pengetahuan Dasar Pada Penanggulangan Pencemaran Lingkungan Air. Tj. JETRO. Jakarta.

Norhadi, A., Akhmad, M., dan Luki, W. 2015. Studi Debit Aliran pada Sungai Antasan Kelurahan Sungai Andai Banjarmasin Utara. Jurnal Poros Teknik. Vol. 7 No.1.

Peraturan Daerah Kota Denpasar Nomor 27 Tahun 2011 tentang Rencana Tata Ruang Wilayah (RTRW) Kota Denpasar Tahun 2011-2031.

Peraturan Gubernur Bali Nomor 16 Tahun 2016 tentang Baku Mutu Lingkungan dan Kriteria Baku Kerusakan Lingkungan Hidup.

Setiari, N.M., Mahendra, M.S., Suyasa, W.B. 2012. Identifikasi Sumber Pencemar dan Analisis Kualitas Air Tukad Sungi di Kabupaten Tabanan dengan Metode Indeks Pencemaran. Jurnal Ecotrophic, 7(1): 40-46. 